\title{
How does Arab genome different from other genomes?
}

\author{
Ibrahim Abdulkareem ${ }^{1,2}$ \\ From 2nd International Genomic Medical Conference (IGMC 2013) \\ Jeddah, Kingdom of Saudi Arabia. 24-27 November 2013
}

Whole-genome sequencing results from Caucasian, African, Chinese and Korean individuals have been studied and published to date. Here, we successfully generated, assembled and analyzed the first full genome of an Arabic individuals (32 healthy volunteers from Saudi Arabia) using Next Generation Sequencing. Alignment of the Arabic genome with H19 references revealed nearly 450,182 unique singlenucleotide polymorphisms (SNPs) out of 3.18 million total SNPs, including 10,609 non-synonymous SNPs and 174,579 Deletion or Insertion Polymorphisms (DIPs). A de novo assembly of 9,011 contigs sequences was identified and which are not represented within the current human reference genome sequence maintained at NCBI. In addition, the assembled Arab mitochondrial genome was closest to the L0a haplogroup sequence of the Datog ethnic group of Tanzania.

\footnotetext{
Authors' details

'Molecular Pathology and Genetics, DPLM, King Abdullah International Medical Research Center, Kingdom of Saudi Arabia. ${ }^{2}$ COM, King Saud bin Abdulaziz University for Health Sciences, King Abdulaziz Medical City, National Guard Health Affairs, Kingdom of Saudi Arabia.
}

Published: 2 April 2014

doi:10.1186/1471-2164-15-S2-O8

Cite this article as: Abdulkareem: How does Arab genome different from other genomes? BMC Genomics 2014 15(Suppl 2):O8.

\footnotetext{
Correspondence: abdulkarimi@ngha.med.sa

${ }^{1}$ Molecular Pathology and Genetics, DPLM, King Abdullah International

Medical Research Center, Kingdom of Saudi Arabia

Full list of author information is available at the end of the article
}

Submit your next manuscript to BioMed Central and take full advantage of:

- Convenient online submission

- Thorough peer review

- No space constraints or color figure charges

- Immediate publication on acceptance

- Inclusion in PubMed, CAS, Scopus and Google Scholar

- Research which is freely available for redistribution
C Biomed Central

(c) 2014 Abdulkareem; licensee BioMed Central Ltd. This is an Open Access article distributed under the terms of the Creative Commons Attribution License (http://creativecommons.org/licenses/by/2.0), which permits unrestricted use, distribution, and reproduction in any medium, provided the original work is properly cited. 